\title{
EDUCATION
}

\section{Those who can, teach}

With so many young people eager to learn about ocean life, marine education can be a promising career path. Whether as a full-time job at an aquarium or at a summer camp on the high seas, explaining marine science to kids can be very rewarding, says Cause Hanna, research manager of the Santa Rosa Island Research Station, part of the California State University Channel Islands. "As a researcher, you can be plugging away on a problem for years," he says. "As an educator, you can get phenomenal results in a day."

According to Jennifer Seavey, executive director of the University of New Hampshire's Shoals Marine Laboratory on Appledore Island, "there are a lot of marine-science camps and courses for kids, and they all need people to teach them". Many of the jobs are at the sorts of places that attract so many people to marine biology. SeaTrek BVI, a company that offers adventure summer camps for teens in the British Virgin Islands, hires biologists to teach kids about coral reefs, mangroves, plankton and other ocean topics. The Marine Discovery Center at New Smyrna Beach in Florida employs biologists to guide dolphin tours, give talks about sharks and starfish to the general public and teach at summer camps for kids and teens.

California's Catalina Island Marine

Institute - a non-profit school for children aged 9-17 - is one of the best destinations for early-career marine biologists who have a penchant for teaching, says George Matsumoto, education specialist at the Monterey Bay Aquarium Research Institute in Moss Landing, California. "It has a large network of alumni all over the world," he says. "Having that on your CV will only help you."

For those who prefer more stable work, Seavey notes that a bachelor's or master's degree in ocean science can be a good foundation for a career teaching at pre-university levels. "It's not uncommon to find high-school teachers with a background in marine biology," she says.

Researchers do not necessarily need formal training to share their knowledge with others, but Matsumoto says that it is important to hone teaching skills when you have the chance. "Postdocs should look around at local community colleges to see if they can get an adjunct or guest lecturer position," he says. "PhD students should ask their professors if they can teach some classes. I did that with my professor, and he was more than happy to oblige." c.W.

Studying marine mammals in the field Mehta assures students who are willing to look beyond academia that jobs are out there. "There are quite a few public research opportunities," she says, including positions with aquariums, non-profit organizations and governments at the federal, state and municipal level. Tetra Tech, a consulting firm based in Research Triangle Park, North Carolina, is seeking an aquatic ecologist, and the Alaska Department of Fish and Game in Dutch Harbor wants a fishery biologist, for example. The inexhaustible pool of interest in ocean science among the general public also opens up opportunities for researchers with a penchant for teaching, Mehta adds (see 'Those who can, teach'). If an earlycareer scientist knows a few things about sea lions, great white sharks or oysters, there will always be people who want to hear about it.

But none of those jobs are easily won. “There are numerous career options," says Erich Hoyt, a researcher with the global nonprofit organization Whale and Dolphin Conservation in Chippenham, UK. "But because so many people want to get into the field, you need dedication and creativity." He says that he received more than 200 applications when he recently put out a call for an assistant. requires an especially diverse skill set, Hoyt says. Among other things, he says, researchers need to be able to handle boats of all sizes, take photos, make sound recordings, sort through streams of data and write papers. Hoyt does all these, as well as giving regular talks and writing popular books, including the 2013 children's book Weird Sea Creatures, a side career that has undoubtedly sent more young people down a path towards a career in ocean science.

What opportunities will those students have? It depends on the student. "There are no guaranteed jobs post-graduation in any field, especially in a competitive area such as marine biology," Davies says. But the picture is not hopeless. "There is always a need for enthusiastic, motivated and hard-working graduates who have the confidence to tackle challenges head on." If that challenge involves spotting blue whales from a boat or scuba diving with a pod of dolphins, so be it. It is a tough job, but some marine biologist will have to do it.

Chris Woolston is a landlocked freelance writer in Billings, Montana.

\section{UNIVERSITIES}

\section{Gloomy outlook}

US universities will probably face financial pressure until at least mid-2016, including an erosion of federal funding, says a report by Moody's Investors Service in New York. The report, 2015 Outlook - US Higher Education: Slow Tuition Revenue Growth Supports Negative Outlook, released on 1 December, predicts that universities will continue to battle for tuition-fee revenue, state funding and federal grants. Moody's, a credit-rating agency, expects federal grant amounts and activity, especially from the US National Institutes of Health and the US National Science Foundation, to decline in the next 12-18 months. It says that the contraction will be a result of discretionary spending cuts, federal budget pressures and the continuing effects of last year's acrossthe-board funding sequestration. Research will increasingly be funded through private donations and gifts, the report predicts. The continued negative outlook, in effect since January 2013, means that Moody's is more likely to give poor credit ratings to US universities, which will incur higher borrowing costs and might be forced to scale back hiring plans.

\section{CAREER PROGRESS}

\section{Informal relations}

Women are more likely to realize career benefits from informal relationships with colleagues and others if they are in a discipline that comprises at least 15\% women and are not simply tokens, finds a study. Cultural Correlates of Gender Integration in Science analysed accounts of scientific success in psychology, psychiatry and the life sciences, which have large proportions of women, and in engineering and physics, in which women tend to be underrepresented. The authors found that informal relationships (including those with colleagues and contacts made through conferences or other means) help women to integrate and stay in their career just as much as mentorships and other formally structured relationships. They suggest that the benefits come from the extra support and opportunities these relationships can provide. Early-career female researchers should assess the collegiality of their fields and workplaces as they make career decisions, says co-author Cindy Cain, a postdoc at the University of Minnesota in Minneapolis. "Friendly relationships may increase women's sense of professional role confidence, thus helping them to fit in and be productive - as long as women have surpassed the $15 \%$ tokenism level in that discipline," Cain says. 